\title{
ASSESSMENT OF MERCURY EMISSIONS AND LOAD OF COAL AND PETROLEUM COKE BURNING AS ENERGY SOURCE IN CEMENT INDUSTRY
}

\begin{abstract}
Hewehy, M. A. ${ }^{(1)}$; Zaki, Gehan, R. $^{(2)}$ and Mustafa, A. S. ${ }^{(3)}$
1) Environmental Basic Science Department, Institute of Environmental Studies and Research, Ain Shams University 2) Occupational Health and Air Pollution Departement, High Institute of Public Health, Alexandria University 3) Central lab, Egyptian Environmental Affairs Agency, Ministry of Environment
\end{abstract}

\begin{abstract}
In Egypt, there is a power crisis. So search on varieties of power sources, especially in the highly consumed energy industries like cement is going in. Hence, Egypt began using coal as an energy source instead of Mazeot and Natural Gas. However, coal combustion emits large amounts of air pollutants as mercury $(\mathrm{Hg})$, sulfur content, carbon content and organic materials. The aim of the present study was to assess mercury emissions from coal burning cement industry at various cement companies that use different types of coal. This study was a descriptive cross-sectional survey that was conducted in Tourah, Helwan, and Arabian Cement Production settings that use coal as an energy source. Stack sampling of both vapor, and particulates' $\mathrm{Hg}$ was conducted according to the standard isokinetic method. Total stack $\mathrm{Hg}$ was then calculated. Helwan Cement plant (Coal) was of the highest $\mathrm{Hg}$ emissions [0.0008 $(0.011) \mathrm{mg} / \mathrm{m} 3]$ followed by Tourah that uses petroleum coke [0.006 $(0.011) \mathrm{mg} / \mathrm{m} 3]$ and Arabian (mixed coal) [0.003(0.006) $\mathrm{mg} / \mathrm{m} 3]$. From the present study we concluded that $\mathrm{Hg}$ emissions of Helwan cement plant (petroleum coke) was higher than that of Tourah (Coal) and Arabian (mixed coal) ones. All plants were compliant with the Egyptian.
\end{abstract}

Key words: Cement industry; Coal; Energy Source, Mercury emission, Mineral coal, Petroleum coke. 
J. Environ. Sci.

Institute of Environmental Studies and Research - Ain Shams University

\section{INTRODUCTION}

Cement production consists of four main stages, including extraction and crushing of raw materials, pyroprocessing, as well as grinding and mixing (Gerbens-Leenes et al., 2018). It is one of the most known energy-consuming industries that are not able to continue with the present situation of energy crises in Egypt (Abdulrahman and Huisingh, 2018). So, the researchers in cement industry search for alternative non-traditional sources of power supply. Coal is one of the earth's energy sources, of which $50 \%$ of the carbonaceous materials are derived from ancient plants. The Indian and Chinese's cement industries use coal as a primary fuel (Verma and Kumar, 2017, Yan et al., 2015).

Mercury is one of the heavy metals, which resulted as metal vapor or as metal compounds adsorbed on dust when coal is burned (Streets et al., 2005, Contreras et al., 2018). Minamata Convention October 2013 recommended reducing the mercury pollution in any ecological matrix (U.N., October 1011, 2013). The Egyptian Environmental law number 9/2009 and its amended executive rule number 964/2015 set the emission limit of mercury produced from coal burning in cement industry as $0.05 \mathrm{mg} / \mathrm{m} 3$ (Prime-Minister, 2015). German and Chinese's emission limits for both vapor and particulates $\mathrm{Hg}$ is $0.03 \mathrm{mg} / \mathrm{m} 3$ (Sloss, 2012).

Health effects of $\mathrm{Hg}$ exposure vary according to its chemical form, whether it is elemental $\mathrm{Hg}$ (vapor), organic or inorganic $\mathrm{Hg}$ (particulates). Mercury vapor may lead to lymphocytic aneuploidy, neurological, reproductive, pulmonary, renal, muscular, and dermal symptoms 
(Vahabzadeh and Balali-Mood, 2016). It can affect the foetus and young children's development (UN, 2013). Inorganic Hg may lead to kidney (Li et al., 2015), and liver damage added to the neurobehavioral impacts (Yang et al., 2016). Organic $\mathrm{Hg}$ is the most hazardous form, of which the main effect is neurological, in addition to the gastrointestinal, respiratory, kidney, liver, and dermal impacts (Risher et al., 2002).

Global emission inventories 2010 indicated that cement production represents about $9 \%$ of the universal anthropogenic mercury emissions (UN, 2013). The mercury emission depends on the chemical composition of the burned coal, especially chlorine, bromine and other halogen contents (Streets et al., 2005). US Environmental Protection Agency classified mercury compounds as hazardous air pollutants (HAPs) due to its toxicity, universal distribution of its sources, and long atmospheric residence time (Selin, 2009) (EPA, 2017). Worldwide studies commissioned by United Nations Environment Programme (UNEP) have confirmed the risks of global mercury emissions (UN, 2013).

In response to the Egyptian energy crisis, the Egyptian Government approved the use of coal fuel for both power generation and cement production, if certain conditions are met (Prime-Minister, 2015). Accordingly, it is necessary to evaluate the mercury emissions from coalburning industries. So the aim of the present study was to assess mercury emissions and load from coal burning cement industry at various cement companies that use different types of coal. 


\section{MATERIAL AND METHODS}

This study was a descriptive cross-sectional survey that was conducted in Tourah, Helwan, and Arabian cement production settings that use coal as an energy source, and accepted to participate in the study. Mercury emissions (particulate or vapor) were sampled using Apex Iso-kinetic sampler - Model X5000 - Year 2012, according to the EPA standard methods. It was collected at a rate of $25 \mathrm{~L} / \mathrm{min}$ for 120 minutes, the first 60 minutes for particulate sampling (six points from two ports) and second for mercury vapor at the same points and ports (US-EPA, 1996). The stack samples represented summer and winter seasons; samples was taken from two stacks built in two production line from each company with total 24 samples (12 samples for each season). Different companies (Tourah, Helwan, and Arabian cement) use different coal types, including petroleum coke, coal, and mixed coals (Hu and Cheng, 2016).

Mercury Samples were analysed using the standard method of ASTM D4185 and Dual amalgamation cold vapor atomic fluorescence spectrometric technique using CVAFS - Shimadzu Co. - 2001 - Japan according to the American Standard Technical Method (ASTM) D4185 (ASTM, 1996-2018). The volume of air sampled, the stack $\mathrm{Hg}$ concentration, and the $\mathrm{Hg}$ environmental load were calculated according to the Standards Method of EPA (EPA-OEE, 2007). 


\section{RESULTS}

In the present study, there were totally 36 samples of stack mercury vapor, 36 of stack mercury particulates. Stack mercury vapor, and particulates did not follow the normal distribution (Kolmogorov-Smirov Test). Hence, the data were expressed as [median (interquartile range IQR)]. In the three companies, the concentrations of mercury emissions in its vapor form were lower than that in particulate ones.

$\mathrm{Hg}$ vapor emissions in Helwan cement plant [0.008(0.011) $\mathrm{mg} / \mathrm{m} 3]$ was higher than that in Tourah $[0.006(0.011) \mathrm{mg} / \mathrm{m} 3]$ and Arabian $[0.003(0.006)$ $\mathrm{mg} / \mathrm{m} 3$ ] plants (Figure (1)). Kruskal-Wallis H Test disclosed its nonsignificant variation among the three plants. They were greatly lower than the Egyptian $(0.05 \mathrm{mg} / \mathrm{m} 3)$, German, and Chinese emission limits $(0.03 \mathrm{mg} / \mathrm{m} 3)$.

Next table shown the found analyses results in compare with the consumed burning coal and petroleum coke and amount of cement produced of each company.

Table (1): Results of Mercury Load from coal and petroleum coke from three cement production plants

\begin{tabular}{||c|c|c|c||}
\hline Company & Tourah & Helwan & Arabian \\
\hline $\begin{array}{c}\text { Average of Cement } \\
\text { Production (Ton/Year) }\end{array}$ & $\begin{array}{c}30,000,000 \text { (EEAA, } \\
\text { 2015c) }\end{array}$ & $\begin{array}{c}5,395,753 \\
\text { (EEAA, 2015b) }\end{array}$ & $4,650,000$ (EEAA, 2015a) \\
\hline $\begin{array}{c}\text { Average of Fuel } \\
\text { Consumed (Ton/Year) }\end{array}$ & $\begin{array}{c}177,343 \text { (EEAA, } \\
\text { 2015c) }\end{array}$ & $\begin{array}{c}144,895 \\
\text { (EEAA, 2015b) }\end{array}$ & 100,129 (EEAA, 2015a) \\
\hline Type of Fuel & Petroleum Coke & Coal & Mixed Coal \\
\hline $\begin{array}{c}\text { Mercury Content in the } \\
\text { Fuel (mg/kg) }\end{array}$ & 0.08 (Stoeppler, 2012) & $\begin{array}{c}0.16 \text { (Stoeppler, } \\
2012)\end{array}$ & $\begin{array}{c}0.16 \text { in 70\% of fuel (as coal } \\
\text { is 70\% of the used fuel) }\end{array}$ \\
\hline $\begin{array}{c}\text { Hg Vapor Load Result } \\
\text { (Ton/Year) }\end{array}$ & 0.3 & 0.6 & 0.1 \\
\hline $\begin{array}{c}\text { Hg Particulate Load } \\
\text { Result (Ton/Year) }\end{array}$ & 1 & 1.1 & 0.3 \\
\hline Total Hg Load (Ton/Year) & 1.3 & 1.7 & 0.4 \\
\hline
\end{tabular}


The environmental mercury load of Helwan Cement plant [0.6 (1.1) vapour (particulate)tons/year] was the highest followed by that of Tourah [0.3(1.0) vapour (particulate)tons/year] and Arabian [0.1(0.3)vapour (particulate)tons/year]. Kruskal-Wallis $\mathrm{H}$ Test revealed non-significant variation of mercury emission load among the three companies.

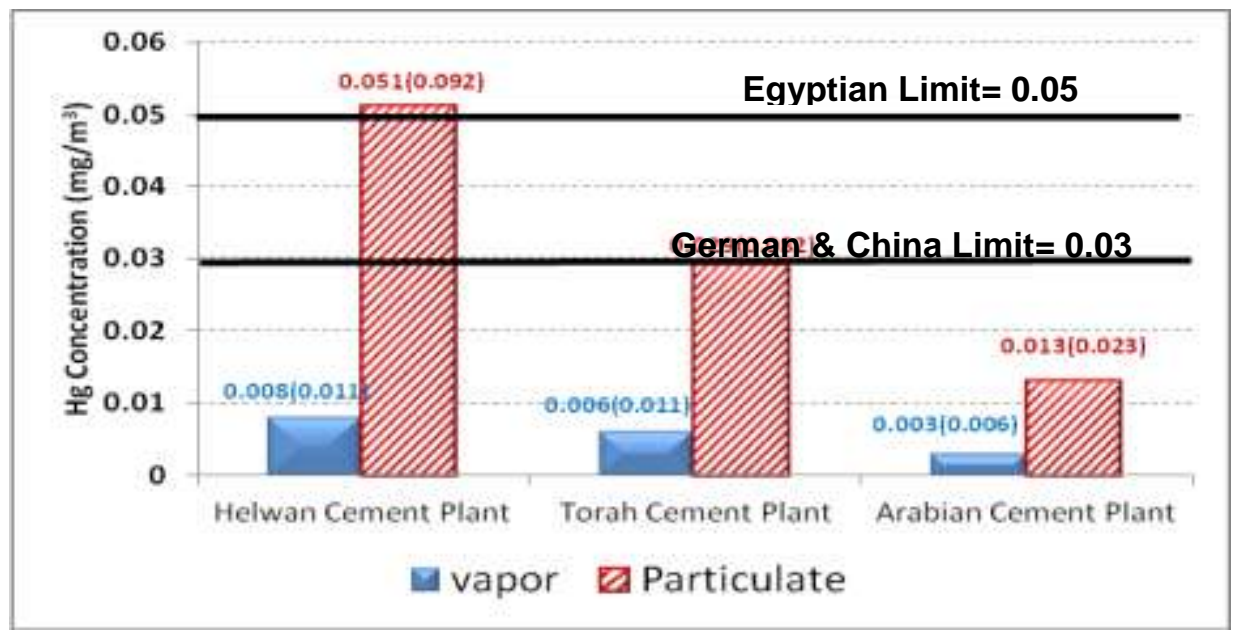

Figure (1): Levels of Mercury emissions (vapor and particulate) from Coal Stacks of different Cement Plants as compared with the Egypt, German, and China limits (2016-2017) 


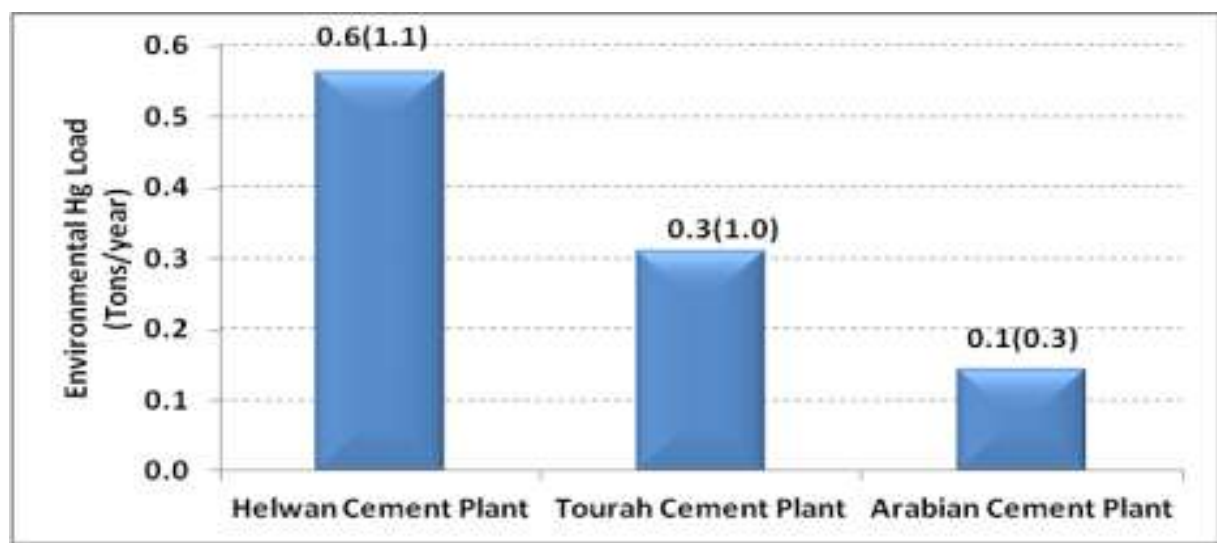

Figure (2): Environmental Load of Mercury Emissions from Coal Stacks of different Cement Plants (2016-2017)

\section{DISCUSSION}

It is important to assess the mercury ( $\mathrm{Hg})$ emissions and the environmental $\mathrm{Hg}$ load from one of its main industrial sources in Egypt, which is cement productions, especially after allowing them to use coal as an energy source. Although Tourah Cement Plant had the highest cement production; Helwan Cement Plant had the greatest $\mathrm{Hg}$ emissions and annual $\mathrm{Hg}$ load followed by Tourah and Arabian. This may be attributed to the type of coal used in each company. Tourah uses petroleum coke, of which the $\mathrm{Hg}$ content $(0.08 \mathrm{mg} / \mathrm{kg}$ coal $)$ is half that of the mineral coal $(0.16 \mathrm{mg} / \mathrm{kg}$ sample) that is used in Helwan Cement Plant (Stoeppler, 2012). The Arabian plant had the lowest $\mathrm{Hg}$ emissions and environmental load. This may be due to two main factors, including the advanced technology as well as the used kind of coal (mixed coal) (Osborne, 2013). Mixed coal is a mixture of mineral coal and organic wastes at a ratio 2:1. This ratio greatly reduces the $\mathrm{Hg}$ 
contents of the mixed coal, and hence, mitigates the environmental $\mathrm{Hg}$ load.

Emissions of $\mathrm{Hg}$ vapor from the three companies were lower than the Egyptian limits of the Egyptian Prime Minister Decree no. 964-2015, annex no. 6, table no. 6 (Prime-Minister, 2015), as well as the German and Chinese limits (Sloss, 2012). Although US EPA considers Hg compounds of the hazardous air pollutants that may adversely affect public and environmental health (EPA, 2017), the Egyptian Environmental Law No 9-2009 and its executive regulation Number 964-2015 did not set standard emission limit for particulate Hg (Prime-Minister, 2015). In addition, China and Germany established the emission limits for both particulate and $\mathrm{Hg}$ vapor (Sloss, 2012).

In the present study, $\mathrm{Hg}$ emissions from the main stacks were higher than that from the by-pass ones. This can be interpreted based on the cement production line that has two stacks; the first is the main stack, which is the major line exhaust where all production and burning gases release from it. The other is the by-pass stack, which act as a secondary exhaust stack to avoid any damage in the production line, which may happen due to the huge amount of heat, excess $\mathrm{CO} 2$, release of particulates and the internal air pressure on the line's body. So, most emissions were logically from the main stacks' location (Osborne, 2013). 


\section{CONCLUSION}

From the present study we concluded that $\mathrm{Hg}$ emissions and environmental loads of Helwan cement plant was higher than that of Tourah and Arabian ones.

\section{RECOMMENDATIONS}

The present study could not recommend using mixed instead of coal or petroleum; so the amount of mercury $(\mathrm{Hg})$ emitted in air will be decrease as the result of the company emissions which use the mixed fuel is low.

\section{RECOMMENDED FUTURE STUDIES}

It is suggested to conduct a study for evaluation of other emission products of mixed coal as compared to that of coal and petroleum coke to enable recommending the most suitable type. Moreover, it is recommended to study the annual mercury load from the three companies. In addition, it is proposed to apply a dispersion model to identify the ambient concentrations of $\mathrm{Hg}$ at different distances from the stacks.

\section{ACKNOWLEDGMENT}

Great thanks are presented to the management of the three companies (Helwan, Tourha, and Arabian cement plants) for their permissions to conduct this study. The authors like to acknowledge the administrative support received from Institute of Environmental Studies and Research. They express great appreciation to the colleagues in the central laboratory, Egyptian Environmental Affairs Agency for their invaluable help to complete this work. 


\section{REFERENCES}

ABDULRAHMAN, A. O. \& HUISINGH, D. (2018). The role of biomass as a cleaner energy source in Egypt's energy mix. Journal of Cleaner Production, 172, 3918-3930.

ASTM, A. S. T. M. (2016). Standard Test Method for Measurement of Metals in Workplace Atmospheres by Flame Atomic Absorption Spectrophotometry. ASTM International.

CONTRERAS, M. L., GANESH, N., RODILLA, I. \& BAHILLO, A. (2018). Assess of biomass co-firing under oxy-fuel conditions on $\mathrm{Hg}$ speciation and ash deposit formation. Fuel, 215, 395-405.

EEAA, E. E. A. A. (2015a). Permission for Arabian Cement Plant to use coal as an energy source issued August 30, 2015 Egypt.

EEAA, E. E. A. A. (2015b). Permission for Helwan Cement Plant to use coal as an energy source issued November 10, 2015. Egypt.

EEAA, E. E. A. A. (2015c). Permission for Tourah Cement Plant to use coal as an energy source issued December 24, 2015. Egypt.

EPA-OEE, O. O. E. E. (2007). Air Emissions Monitoring Guidance Note \#2 (AG2).

Available: https://www.epa.ie/pubs/advice/air/emissions/Air\%20Mon\%20Gu id\%20Note\%20_AG2_\%20-\%20final\%20version2.pdf.

EPA, U. S. (2017). Initial List of Hazardous Air Pollutants with Modifications [Online]. US Environmental Protection Agency. [Accessed January 30, 2018 2018].

GERBENS-LEENES, P. W., HOEKSTRA, A. Y. \& BOSMAN, R. (2018). The blue and grey water footprint of construction materials: Steel, cement and glass. Water Resources and Industry, 19, 1-12.

HU, Y. \& CHENG, H. (2016). Control of mercury emissions from stationary coal combustion sources in China: Current status and recommendations. Environmental Pollution, 218, 1209-1221. 
LI, P., DU, B., CHAN, H. M. \& FENG, X. (2015). Human inorganic mercury exposure, renal effects and possible pathways in Wanshan mercury mining area, China. Environmental Research, 140, 198204.

OSBORNE, D. (2013). The Coal Handbook: Towards Cleaner Production: Volume 2: Coal Utilisation, Elsevier.

PRIME-MINISTER, E. (2015). Prime Minister Decission 964-2015. In: JOURNAL, E. O. (ed.) 16A. Cairo, Egypt: General Authority for Printing Press.

RISHER, J. F., MURRAY, H. E. \& PRINCE, G. R. (2002). Organic mercury compounds: human exposure and its relevance to public health. Toxicology and industrial health, 18, 109-160.

SELIN, N. E. (2009). Global biogeochemical cycling of mercury: a review. Annual Review of Environment and Resources, 34.

SLOSS, L. (2012). Legislation, standards and methods for mercury emissions control. UK: IEA Clean Coal Centre.

STOEPPLER, M. (2012). Sampling and sample preparation: practical guide for analytical chemists, Springer Science \& Business Media.

STREETS, D. G., HAO, J., WU, Y., JIANG, J., CHAN, M., TIAN, H. \& FENG, X. (2005). Anthropogenic mercury emissions in China. Atmospheric Environment, 39, 7789-7806.

U.N. October 10-11, (2013). The Minamata Convention on Mercury [Online]. Japan. Available: http://www.mercuryconvention.org/Convention/tabid/3426/langu age/en-US/Default.aspx [Accessed January 29, 2018 2018].

UN, U. N. (ed.) (2013). Mercury: Time to act, Geneva: United Nations Environment Programme.

US-EPA (1996). Method 0060: Determination of Metals in Stack Emissions. US: US. EPA.

VAHABZADEH, M. \& BALALI-MOOD, M. 2016. Occupational metallic mercury poisoning in gilders. International Journal of Occupational and Environmental Medicine, 7, 116-122. 
VERMA, S. \& KUMAR, S. Y. (2017). A review on thermodynamics analysis and waste energy utilization in cement industry. International Journal of Mechanical and Production Engineering Research and Development, 7, 203-212.

YAN, D., PENG, Z., DING, Q., KARSTENSEN, K. H., ENGELSEN, C. J., LI, L., REN, Y. \& JIANG, C. (2015). Distribution of Hg, As and $\mathrm{Se}$ in material and flue gas streams from preheater-precalciner cement kilns and vertical shaft cement kilns in China. Journal of the Air \& Waste Management Association, 65, 1002-1010.

YANG, D., TAN, X., LV, Z., LIU, B., BAIYUN, R., LU, J. \& ZHANG, Z. (2016). Regulation of Sirt $1 / \mathrm{Nrf} 2 / \mathrm{TNF}-\alpha$ signaling pathway by luteolin is critical to attenuate acute mercuric chloride exposure induced hepatotoxicity. Scientific Reports, 6.

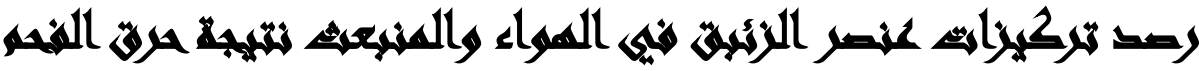

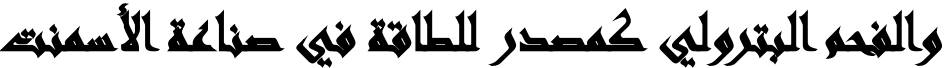

$[r]$

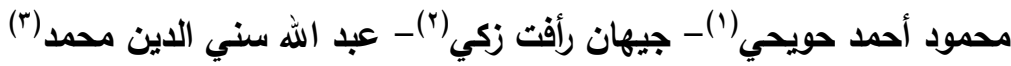

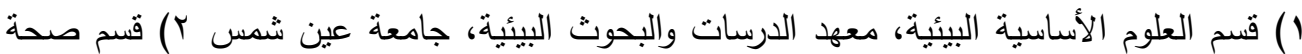

ييئة العمل وتلوث الهواء، المعهد العالي للصحة العامة، جامعة الإسكندرية ب) معمل رصد تلوث

الهواء، جهاز شئون البيئة

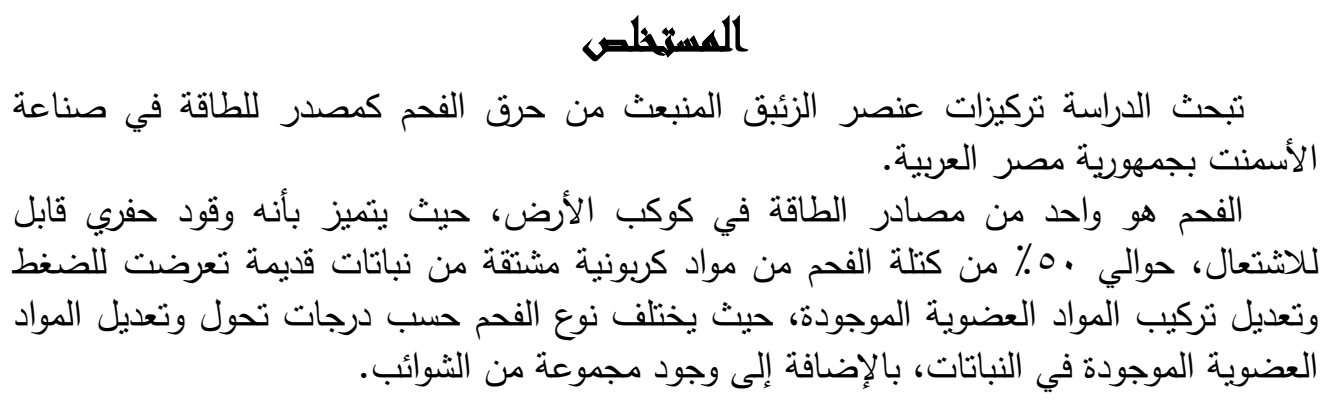


يستخدم الفحم في نطاق واسع اليوم في مصر كمصدر للطاقة بدلا من البترول والغاز الطبيعية في فرع صناعة الاسمنت.

الزئيق هو واحد من المعادن التقيلة التي تتتج كبخار أو مركب من مركبات الزئئق عندما ينت

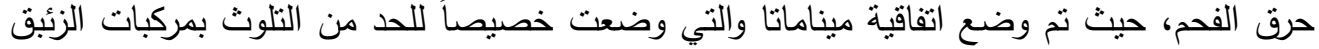

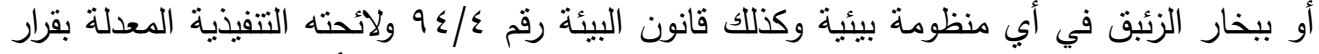

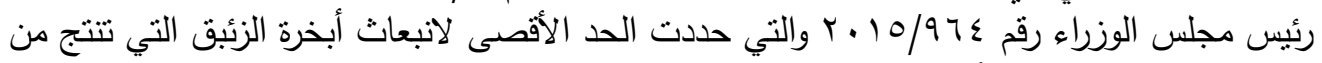

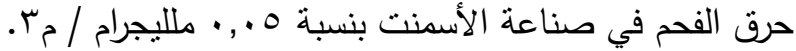

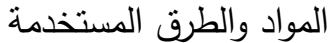
يمكن الحصول على الزئبق الذي تحمله جسيمات الأتربة من:

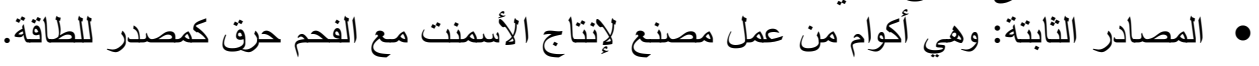
• • • وحدة المصيدة الباردة (Cooled Trap).

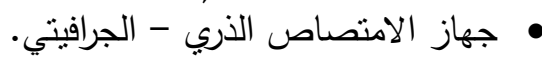

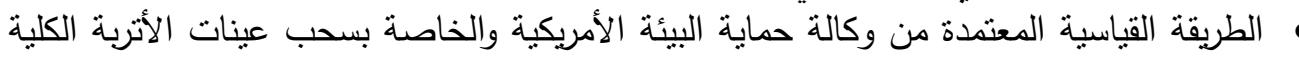
EPA ISO-Kinetic ) من المداخن من خلال جهاز ممانل لحركة الهواء داخل المدخة .(Methods no.5 • الطريقة القياسية المعتمدة من وكالة حماية البيئة الأمريكية والخاصة بسحب عينات المعادن التقبلة

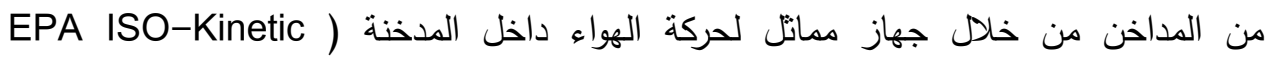
.(Methods no.29 مالطريقة القياسية المعتمدة من وكالة حماية البيئة الأمريكية والخاصة بسحب عينات الأتربة الكلية

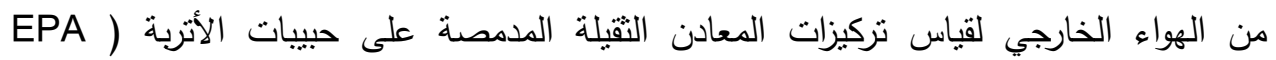
.Compendium Methods IO.5 نم أخذ عينات من الزئبق (الجسيمات أو البخار) باستخدام جهاز أبيكس إيزو -كينيتيك - موديل

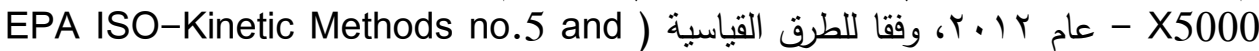
(no. 29 - Appendix I

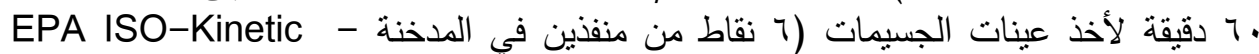

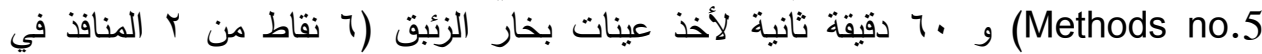

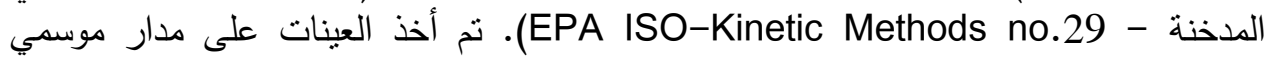
الصيف والثتاء. كما تم سحب العينات حسب خطوط الإنتاج داخل كل شركة حيث تم تحديد

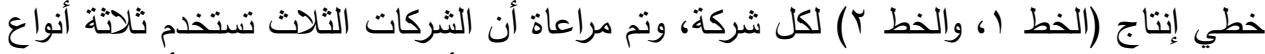

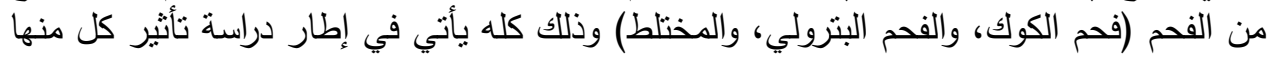
على انبعاثات الزئبق من المداخن.

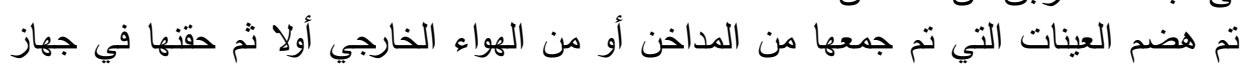

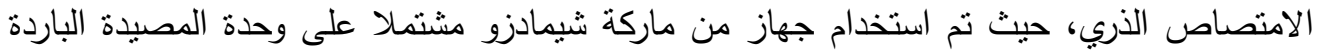
لتحليل تركيزات الزئبق الموجودة في محاليل العينات التي تم جمعها من المداخن سواء كانت عينات 
فلاتر أتربة أو محاليل مؤكسدة وكذللك العينات التي تم جمعها من الهواء الخارجي في المناطق

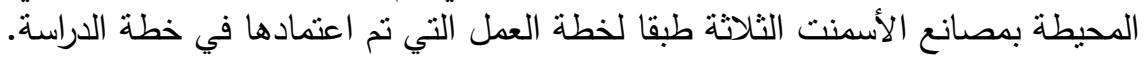

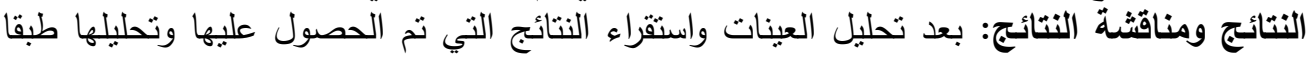
للتحليل الإحصائي تبين الأتي: النيان

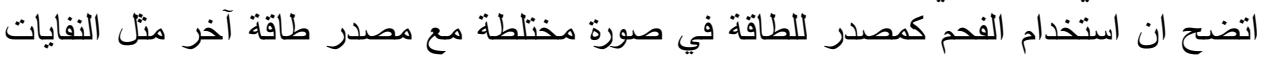

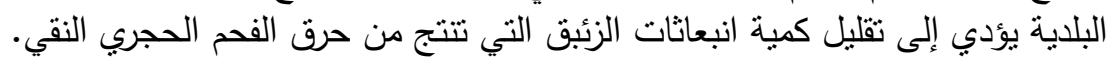

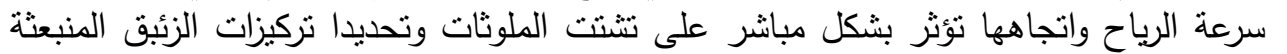

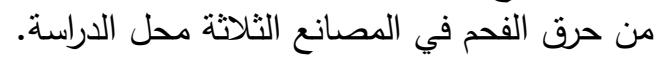

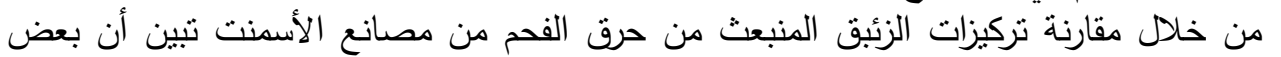

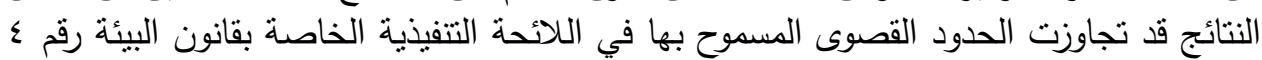

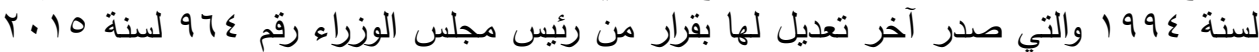

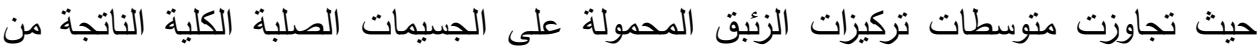

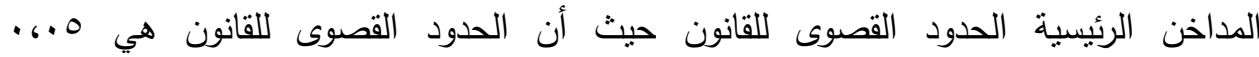

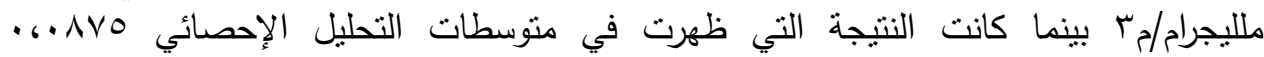

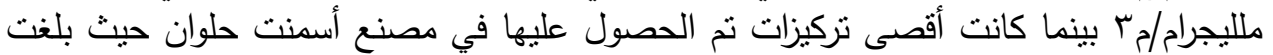
متوسطات تركيزات الزئبق في مداخن شركة أسمنت حلوان التهول 